\title{
MENJADI PENDIDIK YANG TERDIDIK
}

\author{
Sumiati $^{1}$ \\ ${ }^{* 1}$ Pendidikan Agama Islam Fakultas Agama Islam| Unismuh Makassar
}

\begin{abstract}
ABSTRAK
Pendidikan merupakan suatu kegiatan yang universal dalam kehidupan manusia. Di manapun di dunia ini terdapat masyarakat manusia, dan di sana pula terjadi pendidikan. Walaupun pendidikan merupakan gejala umum dalam kehidupan masyarakat, namun perbedaan pandangan hidup, perbedaan falsafah hidup yang dianut oleh masing-masing bangsa atau masyarakat menyebabkan adanya perbedaan penyelenggaraan termasuk perbedaan tujuan pendidikan yang ingin dicapai oleh suatu bangsa atau masyarakat. Kegiatan pendidikan tidak dapat dilepaskan dari yang hendak dicapainya. Bagi manusia pendidikan merupakan suatu keharusan, karena manusia lahir dalam keadaan tidak berdaya, ia sangat membutuhkan bantuan dan bimbingan orang lain untuk dapat berdiri sendiri. Di samping itu manusia lahir tidak langsung dewasa yang mengidentifikasikan manusia dengan moral yang berlaku, dan manusia yang bertanggung jawab, manusia yang sanggup mempertanggungjawabkan segala konsekuensi dan perbuatannya. Oleh karena itu, perbuatan mendidik merupakan perbuatan yang mempunyai tujuan, ada suatu yang ingin dicapai dengan perbuatan tersebut. Orang tua menyuruh anaknya melaksanakan shalat lima waktu, melatih anaknya melaksanakan saum pada bulan ramadhan, melarang anaknya kencing di sembarang tempat dan sambil berdiri, menyekolahkan anaknya dan lain-lain, semuanya itu memiliki maksud dan tujuan yang ingin dicapai, khususnya bagi anaknya.
\end{abstract}

\section{Kata Kunci: Pendidik, Terdidik}

\begin{abstract}
Education is a universal activity in human life. Everywhere in the world there is human society, and there is also education. Although education is a common phenomenon in the life of the community, the differences in life views, differences in the philosophy of life adopted by individual nations or societies lead to different organizational differences, including differences in educational goals to be achieved by a nation or society. Educational activities cannot be separated from what they want to achieve. For human education is a must, because humans are born in a state of helpless, he urgently needs the help and guidance of others to be able to stand on their own. In addition man is born indirectly mature which identifies man with the prevailing morals, and responsible man, man who is able to account for all consequences and actions. Therefore, the act of educating is a purposeful act, there is something to be achieved with the action. Parents asked their children to perform the five daily prayers, to train their children to carry out fasting in Ramadan month, to forbid their children to urinate in any place and to stand up, send their children to school and others, all of which have a purpose and goal to be achieved, especially for their children.
\end{abstract}

\section{Keywords: Educator, Educated}




\section{PENDAHULUAN}

Makhluk paedagogik ialah makhluk Allah yang dilahirkan membawa potensi dapat dididik dan dapat mendidik. Makhluk itu adalah manusia. Dialah yang memiliki potensi dapat dididik dan mendidik sehingga mampu menjadi khalifah di bumi, pendukung dan pengembang kebudayaan. Ia dilengkapi dengan fitrah Allah, berupa bentuk atau wadah yang dapat diisi dengan berbagai kecakapan dan keterampilan yang dapat berkembang, sesuai dengan kedudukannya sebagai makhluk yang mulia. Pikiran, perasaan dan kemampuannya berbuat merupakan komponen dari Fitrah itu. Itulah fitrah Allah yang melengkapi penciptaan manusia, Firman Allah:

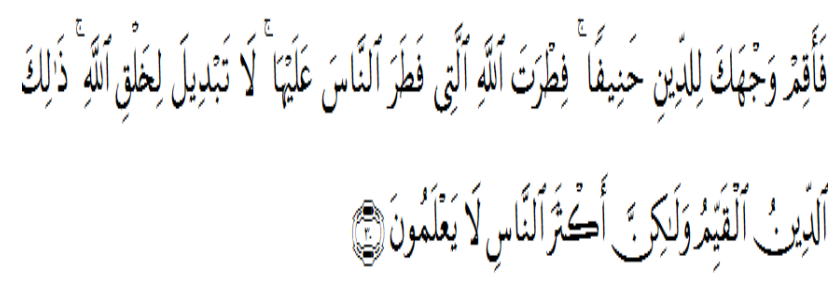

Artinya :

"Maka hadapkanlah wajahmu dengan lurus kepada agama (Allah); (tetaplah atas) fitrah Allah yang telah menciptakan manusia menurut fitrah itu. Tidak ada perubahan pada fitrah Allah. (Itulah) agama yang lurus; tetapi kebanyakan manusia tidak mengetahui, (Q.S. Ar-Rum: 30)

Pendidikan sebagai perbuatan manusia tidak begitu saja dapat dilaksanakan tanpa memperhatikan batas-batas yang mempengaruhinya.
Dalam melaksanakan pendidikan akan terkait beberapa unsur diantaranya: tujuan pendidikan, anak didik sebagai subyek dan dibimbing, pendidik sebagai orang yang membimbing, alat pendidikan, dan lingkungan pendidikan. Selanjutnya pendidik akan sangat mempengaruhi proses pendidikan, bahkan sampai kepada hasil pendidikan. Pendidik memiliki pandangan hidup, dan tujuan hidup sendiri. Pandangan hidup dan tujuan hidup pendidik, kemampuan pendidik, bahkan pribadi pendidik dalam melakukan pendekatan kepada anak dapat berdampak kepada hasil pendidikan anak yang dibimbingnya.

\section{METODE PENELITIAN}

Metode yang digunakan dalam penelitian ini adalah metode deskriptif kualitatif. Penelitian deskriptif merupakan penelitian yang bertujuan menggambarkan suatu kondisi atau fenomena pendidik tidak memilahmilah atau mencari faktor-faktor atau variabel tertentu.

Penelitian kualitatif tidak mengenal istilah populasi melainkan menggunakan istilah "situasi sosial" (social situation) yang memiliki tiga elemen, yaitu tempat (place), pelaku (actors), serta aktivitas (activity) yang berinteraksi secara sinergis dan tidak dapat dipisahkan (Sugiyono, 2009). Teknik yang digunakan dalam penelitian ini, yaitu:
1. Studi Kepustakaan
Pengumpulan data pertama-tama dilakukan melalui pengkajian 
literatur untuk mengungkapkan teori-teori yang relevan dengan topik penelitian

\section{Wawancara}

Wawancara yang dimaksud adalah Wawancara dengan model percakapan kedua belah pihak. Dalam konteks penelitian ini, peneliti merupakan pewawancara dengan mewawancarai para pihak yang dianggap memiliki keterkaitan dengan penelitian ini, yakni; Pemerintah, tokoh masyarakat, masyarakat biasa.

\section{HASIL PENELITIAN DAN PEMBAHASAN}

Dalam proses pendidikan, pendidik memegang peran yang sangat penting dan menentukan dalam mencapai tujuan pendidikan. Pendidik merupakan orang dewasa baik secara kodrati (orang tua) maupun secara profesi (menjadi pendidik karena tugas jabatan) bertanggung jawab dalam menumbuhkembangkan anak didik. Orang tua sebagai pendidik pertama dan utama berkewajiban mendidik anaknya karena kewajaran tanggung jawab dari kehidupan itu sendiri. Pendidik kedua adalah karena jabatan mendapat tugas sementara dari orang tua untuk mendidik anak-anak mereka (para orang tua). Mereka yang termasuk pendidik karena jabatan misalnya guru TK samapi SMA, pembimbing dalam kelompok bermain, pengasuh di rumah yatim piatu dan lainnya.
Pendidik adalah orang dewasa yang membimbing anak agar si anak tersebut bisa menuju kearah kedewasaan. Pendidik merupakan orang yang bertanggung jawab terhadap pelaksanaan pendidikan dengan sasarannya adalah anak didik. Anak didik mengalami pendidikannya dalam tiga lingkungan, yaitu lingkungan keluarga, lingkungan sekolah, dan lingkungan masyarakat. Oleh karena itu, yang bertanggung jawab terhadap pendidikan anak didik di lingkungan keluarga adalah orang tua, di lingkungan sekolah adalah guru, di lingkungan masyarakat adalah orang-orang yang terlibat dalam kegiatan pendidikan, seperti pengasuh anak yatim piatu, pembimbing dalam kelompok bermain. Pendidikan berlangsung dalam pergaulan, seperti dikemukakan Langeveld (1980): tiaptiap pergaulan anatara orang dewasa (orang tua, guru, dsb) dengan anak merupakan lapangan atau suatu tempat dimana perbuatan mendidik berlangsung.

Orang tua (ayah dan ibu) merupakan pendidik kodrati pada hakikatnya tidak bisa digantikan oleh orang lain. Karena itu orang tua menyekolahkan anaknya ke sekolah untuk di didik oleh guru, tidak berarti guru akan menggantikan semua peran orang tua dalam mendidik anak di sekolah. guru harus bertindak mewakili orang tua anak dalam melaksanakan tugasnya. Seorang pendidik baik orang tua atau guru sebagai orang yang orang tua memiliki keterbatasan. Hubungan anak- orang tua berlangsung sejak anak belum sadar akan kehidupan ini. Ia 
menyadari dirinya di tengah pergaulan dengan orang tuanya. Seolah-olah anak menyadari dirinya justru di tengahtengah kehidupan orang tuanya. Dan kesadaran itu tumbuh secara alamiah, begitu juga seorang anak adalah alamiah dalam merasakan bahwa ia berada dalam lindungan orang tuanya. Maka dari itu hubungan anak-orang tua adalah sebagai hubungan yang alamiah, sebab memang tidak ada hal yang dilakukan dengan maksud dibjuat-buat. Orang tua dalam menyayangi anaknya bukan untuk dipuji tapi secara alami hadir dengan sendirinya kasih sayang itu. Sebagaimana dalam Firman Allah seperti yang tersebut dalam Al-Qur'an, yang artinya:

\section{"Peliharalah dirimu dan anggota keluargamu dari ancaman neraka".}

"Dirimu" yang disebut dalam ayat itu adalah diri orang tua anak tersebut, yaitu ayah dan ibu; "anggota keluarga" dalam ayat ini ialah terutama anak-anaknya. Maka dari itu tugas pendidik dalam pandangan Islam secara umum ialah mendidik, yaitu mengupayakan perkembangan seluruh potensi anak didik, baik potensi psikomotor, kognitif, maupun potensi afektif. Potensi itu harus dikembangkan secara seimbang sampai ke tingkat setinggi mungkin, menurut ajaran Islam. Karena orang tua adalah pendidik pertama dan utama, maka inilah tugas orang tua tersebut.

\section{Jenis-jenis Pendidik}

Orang tua secara wajar menjadi pendidik karena mereka merasa bertanggung jawab terhadap anaknya. Sehingga dengan tanggung jawab itu mengundang para orang tua untuk membantu berkembangnya si anak, dan membantu perkembangan itulah di sebut mendidik. Peran pendidik pertama ini sangat besar, karena bukan saja sekedar mendidik anak agar ia menjadi besar dan pandai segala macam, namun terutama ia membantu perkembangan anak dalam segi kemanusiaannya, menjadikan anak didik menjadi manusia yang mampu hidup bersama dengan orang lain, manusia bermoral dan berhati nurani.

Orang tua merupakan pendidik utama dan pertama bagi anak-anak mereka, karena merekalah anak mulamula menerima pendidkan. Dengan demikian bentuk pertama dari pendidikan terdapat dalam kehidupan keluarga. Pada umumnya pendidikan dalam rumah tangga itu bukan berpangkal tolak dari kesadaran dan pengertian yang lahir dari pengetahuan mendidik, melainkan karena secara kodrati suasana dan strukturnya memberikan kemungkinan alami membangun situasi pendidikan. Situasi pendidikan itu terwujud berkat adanya pergaulan dan hubungan pengaruh mempengaruhi secara timbal balik antara orang tua dan anak. Orang tua atau ibu dan ayah memegang peranan yang penting dan amat berpengaruh atas pendidikan dan anak-anaknya. Sejak seorang anak lahir, ibunyalah yang selalu ada di sampingnya. 
Oleh karena itu ia meniru perangai ibunya dan biasanya, seorang anak lebih cinta kepada ibunya, apabila ibu itu menjalankan tugasnya dengan baik. Ibu merupakan orang yang mulamula dikenal anak, yang mula-mula menjadi temannya dan yang mulamula di percayainya. Apapun yang dilakukan ibu dapat dimaafkannya, kecuali apabila ia ditinggalkan. Dengan memahami segala sesuatu yang terkandung di dalam hati anaknya, juga jika anak telah mulai agak besar, disertai kasih sayang, dapatlah ibu mengambil hati anaknya untuk selama-lamanya.

Menurut Husain Mazhahiri mengemukakan bahwa pengaruh orang tua sangat brsar terhadap masa depan anak, seperti beliau kemukakan:

Kita dapat memastikan bahwa komitmen orang tua terhadap norma-norma Islam dan hukumhukumnya pada kehidupan mereka, menyediakan lahan yang sesuai bagi kemaslahatan dan kebahagiaan anak, agar ia dapat tumbuh dengan akhlak yang mulia dan diridhai. Perkara itu dapat menjadi sebaliknya, seandainya orang tua mengabaikan komitmen mereka terhadap hukum-hukum Islam dan ajarannya. (Husain Mazhahiri, 2002: xv).

Menurut Mazhahiri pengaruh orang tua sangat besar terhadap masa depan anak dan nasib anak apakah akan mendapat kebahagiaan atau kesengsaraan. Beliau memberikan contoh orang tua yang tidak mempersoalkan sumber harta kekayaannya, apakah diperolehnya secara subhat atau haram, kemudian dimakan oleh anaknya. Hal tersebut akan berpengaruh langsung terhadap watak yang buruk dan menyimpang pada diri anak.

Dari uraian di atas dapat disimpulkan bahwa terdapat pengaruh langsung dari orang tua terhadap masa depan anak pada berbagai jenjang kehidupannya, baik pada periode kanak-kanak, remaja, dan dewasa. Karena itu Islam menganggap tugas pendidikan anak sebagai suatu kewajiban bagi orang tua yang harus didahulukan.

Guru adalah pendidik profesional, karena secara implisit ia telah merelakan dirinya menerima dan memikul sebagian tanggung jawab pendidikan yang terpikul di pundak para orang tua. Mereka ini, tatkala menyerahkan anaknya ke sekolah, sekaligur berarti pelimpahan sebagian tanggung jawab pendidikan anaknya kepada guru. Hal itu pun menunjukkan pula bahwa orang tua tidak mungkin menyerahkan anaknya kepada sembarang guru/sekolah karena tidak sembarang orang dapat menjadi guru. Sebagaimana diketahui bersama bahwa syarat menjadi guru yang baik dan berhasil, meliputi:

a. Guru harus berijazah, yang dimaksud ijazah di sini adalah ijazah yang dapat memberi wewenang untuk menjalankan tugas sebagai seorang guru di suatu sekolah tertentu.

b. Guru harus sehat rohani dan jasmani, kesehatan jasmani dan rohani merupakan salah satu syarat 
penting dalam setiap pekerjaan. Karena, orang tidak akan dapat melaksanakan tugasnya dengan baik jika ia diserang suatu penyakit. Sebagai seorang guru syarat tersebut merupakan syarat mutlak yang tidak dapat diabaikan. Misalnya saja seorang guru yang sedang terkena penyakit menular tentu saja akan membahayakan bagi peserta didiknya.

c. Guru harus bertakwa kepada Tuhan Mang Maha Esa dan berkelakuan baik. Sesuai dengan tujuan pendidikan, yaitu membentuk manusia susila yang bertakwa kepada Tuhan Yang Maha Esa maka sudah selayaknya guru sebagai pendidik harus dapat menjadi contoh dalam melaksanakan ibadah dan berkelakuan baik.

d. Guru haruslah orang yang bertanggung jawab

Tugas dan tanggung jawab seorang guru sebagai pendidik, pembelajar, dan pembimbing bagi peserta didik selama proses pembelajaran berlangsung yang lebih dipercayakan orang tua/wali kepadanya hendaknya dapat dilaksanakan dengan sebaikbaiknya. Selain itu, guru juga bertanggung jawab terhadap keharmonisan perilaku masyarakat dan lingkungan di sekitarnya.

e. Guru di Indonesia harus berjiwa nasional

Bangsa Indonesia terdiri dari beberapa suku bangsa yang mempunyai bahasa dan adat istiadat berlainan. Untuk menanamkan jiwa kebangsaan merupakan tugas utama seorang guru, karena itulah guru harus terlebih dahulu berjiwa nasional.

Namun selain dari lima persyaratan diatas yang merupakan persyaratan umum untuk menjadi seorang guru, ada pula syarat lain yang sangat erat hubungannya dengan tugas guru di sekolah, sebagai berikut:

1. Harus adil dan dapat dipercaya

2. Sabar, rela berkorban, dan menyayangi peserta didiknya.

3. Memiliki kewibawaan dan tanggung jawab akademis.

4. Bersikap baik pada rekan guru, staf di sekolah, dan masyarakat.

5. Harus memiliki wawasan pengetahuan yang luas dan menguasai benar mata pelajaran yang dibinanya.

6. Harus selalu introsfeksi diri dan siap menerima kritik dari siapapun.

7. Harus berupaya meningkatkan pendidikan ke jenjang yang lebih tinggi.

Sebagai kesimpulan, keberhasilan seorang guru dalam melaksanakan tugas dan tanggung jawabnya sebagai seorang pengajar sangat tergantung pada diri pribadi masing-masing guru dalam lingkungan tempat ia bertugas.

Oleh sebab itu, baik orang tua/ pendidik dan anak/peserta didik keduanya memegang peranan penting di dalam proses pendidikan. Di sini ditekankan kepada orang tua/pendidik 
hendaknya merencanakan proses pendidikan tersebut dengan sebaikbaiknya, sedangkan anak didik diharapkan dapat mengikuti secara aktif agar tujuan dari proses pendidikan itu dapat tercapai. Guru/pendidik jangan hanya memindahkan pengetahuan, keterampilan, bahkan sikap sematamata, dan anak atau peserta didik jangan dianggap wadah yang dapat diisi apa saja oleh orang tua/ pendidikan. Maksudnya adalah bahwa pencapaian dari orang tua/pendidik bukan hanya sekedar melepas kewajiban masing-masing akan tetapi mampu mendidik secara keseluruhan untuk membentuk akhlak mulia.

\section{Pendidik Yang Terdidik}

Menurut Ki Hajar Dewantara “ Mendidik adalah menuntun segala kekuatan kodrat yang ada pada anakanak agar mereka sebagai manusia dan sebagai anggota masyarakat dapat mencapai keselamatan dan kebahagiaan yang setinggi-tingginya". Dan ditambahkan lagi bahwa "Pendidikan itu dimulai sejak anak dilahirkan dan berakhir setelah ia meninggal dunia. Jadi pendidikan itu berlangsung seumur hidup". Oleh sebab itu, peranan orang tua sebagai pendidik yang sekaligus pelindung, haruslah memberikan didikan dengan penuh kasih sayang, keikhlasan, dan ketulusan.

Tampaknya saya lebih setuju untuk menyebut "Menteri Pengajaran Nasional" daripada "Menteri Pendidikan Nasional." Sebab yang diperhatikan lebih pada penguasaan knowledge daripada value. Akibatnya banyak orang pintar di negeri kita tanpa nilai dan moral yang berkarakter. Sekolah hanya banyak menghasilkan manusia terpelajar, tetapi sedikit menghasilkan manusia terdidik. Seringkali saya mendengar, melihat atau membaca bahwa banyak sekali orang-orang pintar di negeri ini, tapi masih saja kondisi bangsa yang terpuruk belum juga usai. Bukannya karena mereka tidak ahli menyelesaikan masalah atau kurang pengetahuan untuk memperbaiki negeri, tapi mengapa tak ada perubahan yang bermakna buat anak bangsa yang masih di tepi jalan kesejahteraan.

Kalau kita lihat kamus, "pendidikan" diartikan "proses pengubahan sikap atau tata laku seseorang atau kelompok orang dalam usaha mendewasakan manusia melalui cara pengajaran dan pelatihan." Sedangkan "pengajaran" diartikan proses atau cara mengajar. Adapun "mengajar" berarti "memberi pelajaran" dan "pelajaran" berarti "sesuatu yang dipelajari atau yang diajarkan." Kata "terpelajar" berarti "telah mendapatkan pelajaran (di sekolah)." Sedangkan kata "terdidik" berarti "telah mendapatkan didikan." Jadi sebetulnya berbeda antara "terpelajar" dengan "terdidik," jika yang pertama adalah orang yang berpengetahuan, dan yang kedua adalah orang yang terarah. Arti terdidik ini didasarkan pada arti “didik" yang artinya mengarahkan.

"Mengarahkan" ini penting dalam rangka mengubah sikap 
seseorang, dari yang tidak bermoral menjadi bermoral, dari yang tidak memiliki keberpihakan menjadi orang yang memiliki keberpihakan, dari orang yang tidak memiliki integritas menjadi orang yang memiliki integritas. Itulah orang atau manusia yang terdidik. Ada banyak orang terpelajar tapi ia tidak terdidik. Ia bisa dengan mudah melacurkan keterpelajarannya hanya untuk kepentingan-kepentingan sesaat dan individu. Inilah yang kemudian disebut dengan "bunuh diri intelektual" atau saya menyebutnya dengan "pelacuran intelektual."

Manusia terdidik adalah manusia yang mempunyai kepekaan sosio-transendental. Manusia terdidik tidak merasa nyaman hanya duduk bertengger di menara gading ilmunya. Manusia terdidik selalu berbicara kebenaran atas nama kebenaran, bukan atas nama kekuasaan. Memang tak ada yang indah jika bicara tentang idealisme, tapi tak ada yang lebih indah selain bicara kebenaran. Orangorang suci dahulu kala, nabi-nabi, para rasul, dan para guru suci selalu menekankan akan indahnya kebenaran, meski harus ditebus dengan darah. Itulah hakikat manusia terdidik.

Kemudian kembali di tekankan lagi oleh Ki Hajar Dewantara (Bapak Pendidikan Nasional) mengartikan pendidikan sebagai upaya untuk memajukan budi pekerti, pikiran serta jasmani anak, agar dapat memajukan kesempurnaan hidup dan menghidupkan anak yang selaras dengan alam dan masyarakatnya.
Untuk lebih memahami, berikut adalah pengertiannya :

Pendidikan adalah usaha sadar dan terencana untuk mewujudkan suasana belajar dan proses pembelajaran agar peserta didik secara aktif mengembangkan potensi dirinya untuk memiliki kekuatan spiritual keagamaan, pengendalian diri, kepribadian, kecerdasan, akhlak mulia, serta keterampilan yang diperlukan dirinya, masyarakat, bangsa dan Negara.

Pendidik adalah tenaga kependidikan yang berkualifikasi sebagai guru, dosen, konselor, pamong belajar, widyaiswara, tutor, instruktur, fasilitator, dan sebutan lain yang sesuai dengan kekhususannya, serta berpartisipasi dalam menyelenggarakan pendidikan.

Mendidik adalah usaha yang lebih ditujukan kepada pengembangan budi pekerti, semangat, kecintaan, rasa kesusilaan, dan ketakwaan melalui proses menyampaikan nilai-nilai agar peserta didik mempunyai kecakapan yang lebih baik

Peserta didik adalah anggota masyarakat yang berusaha mengembangkan potensi diri melalui proses pembelajaran yang tersedia pada jalur, jenjang, dan jenis pendidikan tertentu.

Belajar adalah proses membangun makna atau pemahaman terhadap informasi dan pengalaman

Mengajar adalah aktifitas kompleks yang dilakukan pendidik/ dalam menyampaikan pengetahuan kepada peserta didik, sehingga terjadi 
proses belajar. Aktivitas kompleks yang dimaksud antara lain adalah :

1. Mengatur kegiatan belajar siswa,

2. Memanfaatkan lingkungan, baik ada di kelas maupun yang ada di luar kelas,

3. Memberikan bimbingan pengarahan, dan dorongan kepada siswa

Pembelajaran adalah proses interaksi antara peserta didik dengan pendidik dan sumber belajar dalam suatu lingkungan belajar / suatu proses belajar mengajar untuk mencapai suatu tujuan.

Oleh sebab itu, jika ditelaah dengan baik uraian diatas tentang pendidik yang terdidik maka dapat disimpulkan bahwa, pendidikan yang dijalani dewasa ini, tentu saja masih harus belajar bagaimana mendidik pendidik dalam pendidikan. Namun tentu tidak hanya tanggung jawab pendidik semata, tetapi juga para pengambil keputusan pendidikan di negeri ini. Seperti beban kurikulum, ujian nasional, pendidikan yang lebih merata di seluruh penjuru tanah air, tawuran pelajar, sinkronisasi materi pelajaran dengan kebutuhan tenaga kerja yang siap pakai, dll. Jadi mari kita belajar lagi agar menjadi pendidik yang tidak sekadar mendidik tetapi mampu memberikan arahan, saran, nasehat, perlindungan dan yang paling utama adalah menyampaikan semua hsl dengan hati, cinta dan kasih sayang. Dan pendidik sejati adalah pendidik yang mampu memberikan ilmu dan pengetahuannya untuk kemaslahatan umat dalam hal ini anak (peserta didik) sebagai generasi penerus bangsa.

\section{KESIMPULAN}

1. Seorang pendidik baik orang tua atau guru sebagai orang yang mewakili orang tua memiliki keterbatasan. Hubungan anak orang tua berlangsung sejak anak belum sadar akan kehidupan ini. Ia menyadari dirinya di tengah pergaulan dengan orang tuanya. Seolah-olah anak menyadari dirinya justru di tengah-tengah kehidupan orang tuanya. Karena orang tua merupakan pendidik utama dan pertama bagi anak-anak mereka, karena dari merekalah anak mula-mula menerima pendidikan. Dengan demikian bentuk pertama dari pendidikan terdapat dalam kehidupan keluarga. Dan untuk mendapatkan didikan yang semestinya, maka orang tua sebagai pendidik terlebih dahulu harus mendidik dirinya sendiri. Contoh, orang tua harus mengerti apabila anak dibesarkan dengan bentakan maka kelak besarnya nanti anak tersebut akan menjadi pembangkang, sebaliknya anak dibesarkan dengan kasih sayang besarnya nanti anak tersebut akan mampu menyayangi dan pantas disayangi oleh orang lain, itulah hakikat dari didikan orang tua sebagai pendidik utama dan pertama.

2. Guru adalah pendidik profesional, karenanya secara implisit ia telah merelakan dirinya menerima dan 
memikul sebagian tanggung jawab pendidikan yang terpikul di pundak para orang tua. Mereka ini, tatkala menyerahkan anaknya ke sekolah, sekaligus berarti pelimpahan sebagian tanggung jawab pendidikan anaknya kepada guru. Hal itupun menunjukkan pula bahwa orang tua tidak mungkun menyerahkan anaknya kepada sembarang guru/ sekolah karena tidak sembarang orang dapat menjadi guru. Maka dari itu, seorang guru harus memiliki akhlak yang baik, diantaranya:

a. Mencintai jabatannya sebagai guru

b. Bersikap adil terhadap semua muridnya

c. Berlaku sabar dan tenang

d. Guru harus berwibawa

e. Guru harus gembira

f. Guru harus bersifat manusiawi

g. Bekerjasama dengan guru-guru lain

h. Bekerjasama dengan masyarakat

Manusia terdidik adalah manusia yang mempunyai kepekaan sosiotransendental. Manusia terdidik tidak merasa nyaman hanya duduk bertengger di menara gading ilmunya. Manusia terdidik selalu berbicara kebenaran atas nama kebenaran, bukan atas nama kekuasaan. Memang tak ada yang indah jika bicara tentang idealisme, tapi tak ada yang lebih indah selain bicara kebenaran. Orangorang suci dahulu kala, nabi-nabi, para rasul, dan para guru suci selalu menekankan akan indahnya kebenaran, meski harus ditebus dengan darah. Itulah hakikat manusia terdidik

\section{DAFTAR PUSTAKA}

Ahmadi. A, dkk, Ilmu Pendidikan, (Penerbit: Rineka Cipta, Jakarta: 2001)

Daradjat. Z, dkk, Ilmu Pendidikan Islam, (Penerbit: Bumi Aksara: 2008)

Sadulloh.U, dkk, Pedagogik (ilmu mendidik), (Penerbit: Alfabeta, Bandung: 2010)

Mudlofir.A, Pendidik Profesional, (Penerbit: Rajagrafindo Persada: 2012)

Sukardjo. M, dkk, Landasan Pendidikan Konsep dan Aplikasinya, (Penerbit: Rajagrafindo Persada: 2010)

Tafsir. A, Ilmu Pendidikan Dalam Perspektif Islam, (Penerbit: Remaja Rosdakarya, Bandung: 2005)

Uno.B.Hamzah, Profesi Kependidikan problema, solusi, dan reformasi pendidikan di Indonesia, (Penerbit: Bumi Aksara: 2016)

Zuhairini.dkk, Filsafat Pendidikan Islam, (Penerbit: Bumi Aksara, 1995) 